\title{
Experimental and Exergetic Evaluation of Ethanol Catalytic Steam Reforming in a Membrane Reactor
}

Ali Hedayati, Institute of Energy Technologies, Universitat Politècnica de Catalunya, Diagonal 647, 08028 Barcelona, Spain, ali.hedayati@upc.edu

Olivier Le Corre, Department of Energy Systems and Environment, Ecole des Mines de Nantes, 4 rue A. Kastler, 44307 Nantes, France, Olivier.Le-Corre@mines-nantes.fr

Bruno Lacarrière, Department of Energy Systems and Environment, Ecole des Mines de Nantes, 4 rue A. Kastler, 44307 Nantes, France, bruno.lacarriere@mines-nantes.fr

Jordi Llorca, Institute of Energy Technologies, Universitat Politècnica de Catalunya, Diagonal 647, 08028 Barcelona, Spain, jordi.llorca@upc.edu

Corresponding Author: Ali Hedayati, ali.hedayati@upc.edu, Universitat Politecnica de Catalunya, Diagonal 647, ETSEIB Pav. C, INTE, 08028 Barcelona, Spain

\section{Abstract}

The application of exergy analysis in the evaluation of the ethanol steam reforming (ESR) process in a catalytic membrane reactor (CMR) was presented. ESR experiments were performed at $\mathrm{T}=873-923 \mathrm{~K}$ and $\mathrm{P}=4-12$ bar in a CMR containing $\mathrm{Pd}-\mathrm{Ag}$ membranes sandwiched by $\mathrm{Pd}-\mathrm{Rh} / \mathrm{CeO}_{2}$ catalyst, aiming to produce fuel cell grade pure hydrogen. The effect of the operating conditions on the pure hydrogen production rate, hydrogen yield and recovery, exergy efficiency, and thermodynamic losses was investigated. Total hydrogen yield of $3.5 \mathrm{~mol} \mathrm{H}_{2}$ permeated per mol ethanol in feed with maximum hydrogen recuperation of $90 \%$ were measured at $923 \mathrm{~K}$ and 12 bar. The highest amount of exergy was destructed via heat losses and the retentate gas stream. Exergy efficiency up to around $50 \%$ was reached in the case of the insulated reactor at 12 bar and $923 \mathrm{~K}$. The exergy efficiency of the reformer was increased remarkably by recovery of the retentate gas or reactor insulation. Exergy efficiency placed between $70-90 \%$ in the case of recovery of the retentate gas in an insulated reactor. It was concluded that operating at the highest pressure, the lowest $\mathrm{S} / \mathrm{C}$ ratio, and $923 \mathrm{~K}$ gives the best exergy efficiency. 
Keywords: exergy, hydrogen, catalytic membrane reactor, ethanol steam reforming

\section{Introduction}

As an alternative to fossil fuels, hydrogen is considered as a clean energy carrier that can be combusted similar to the conventional carbonaceous fuels or be converted to electricity by fuel cells [1]. The use of renewable biofuels such as bio-ethanol as a source of hydrogen is highly beneficial due to the higher $\mathrm{H} / \mathrm{C}$ ratio, lower volatility and toxicity, and higher safety of storage that distinguishes ethanol over other substrates. Bio-ethanol is cheaply and easily obtained from biomass and organic waste and can be used directly in catalytic steam reforming processes to produce hydrogen since it contains large amounts of water [2]. Among the reforming processes, steam reforming of bio-ethanol (eq. 1) delivers the highest amount of hydrogen per mole of converted bio-ethanol [3].

$\mathrm{C}_{2} \mathrm{H}_{5} \mathrm{OH}+3 \mathrm{H}_{2} \mathrm{O} \leftrightarrow 2 \mathrm{CO}_{2}+6 \mathrm{H}_{2}$

Huge amount of works has been reported in the literature on catalytic ethanol steam reforming (ESR) specially on the experimental investigations aiming for hydrogen generation using a variety of catalysts in different reactor configurations [4-8]. The distinctive properties of noble metals such as high activity, hindering carbon from depositing on the catalyst active sites, and durability and robustness during the ESR process have attracted the attention of a lot of research groups toward such catalysts $[9,10]$. Further, the formation of undesired chemical species is minor or zero when noble metal based catalysts are used for the ESR process $[6,9]$. The main products of ESR over the $\mathrm{Pd}-\mathrm{Rh} / \mathrm{CeO}_{2}$ catalyst are $\mathrm{CH}_{4}, \mathrm{CO}_{2}, \mathrm{CO}$ and $\mathrm{H}_{2}$, which are obtained via following reaction pathways [10-12]:

$$
\begin{aligned}
& \mathrm{C}_{2} \mathrm{H}_{5} \mathrm{OH} \rightarrow \mathrm{H}_{2}+\mathrm{CO}+\mathrm{CH}_{4} \\
& \mathrm{CO}+\mathrm{H}_{2} \mathrm{O} \leftrightarrows \mathrm{H}_{2}+\mathrm{CO}_{2} \\
& \mathrm{CH}_{4}+\mathrm{H}_{2} \mathrm{O} \leftrightarrows 3 \mathrm{H}_{2}+\mathrm{CO}
\end{aligned}
$$


Equations 2 to 4 represent ethanol decomposition, water gas shift reaction (WGS), and methane steam reforming (MSR) reactions, respectively. According to ldriss et al. [10], at T>800 K, the only present non-condensable products of the ethanol steam reforming over the $0.5 \mathrm{wt} \% \mathrm{Pd}-0.5 \mathrm{wt} \%$ $\mathrm{Rh} / \mathrm{CeO}_{2}$ are $\mathrm{CO}, \mathrm{CO}_{2}, \mathrm{CH}_{4}$, and $\mathrm{H}_{2}$. The experiments were performed in a membrane reactor with selective Pd-based metallic membranes in which the production and separation of hydrogen took place simultaneously. The benefits of catalytic membrane reactors (CMRs) such as simultaneous generation and separation of hydrogen, cost reduction, simplicity of the design, and reforming reactions promotion beyond the equilibrium limits (the shift effect) are well known and repeatedly reported in the literature [13-16].

According to the open literature, there are a few reported studies on exergetic efficiency evaluation of ethanol steam reforming systems for hydrogen production. The term exergy is defined as the maximum work that can be obtained theoretically from a system interacting with the source environment to equilibrium [17]. .

The main difference between energy (thermal) efficiency and exergy efficiency lies in the consideration of the thermodynamic state of every single component, which results in an exact understanding of the available amount of work, together with the unavoidable irreversibility during a process [18]. Considering the conservation of mass and energy together, exergy analysis is a powerful tool to investigate the imperfections of single components of a system, to obtain a clearer understanding of the local irreversibility andthe effect of thermodynamic factors on the performance of an energy system.[19,20].

As reported in the literature, Kalinci et al. [21] studied the production of hydrogen via a gasificationboiler system based on experimental data taken from the literature using different types of biomass. They found the maximum exergy efficiency to be about $12 \%$. An exergy analysis of the biological hydrogen production from biomass was done by Modarresi et al. [22] based on experimental results. They reported exergetic efficiencies of $36-45 \%$, depending on the process configuration. For reforming processes, Simpson et al. [1] modelled the methane steam reforming 
process and both irreversible chemical reactions and heat losses were identified as the main source of exergy destruction, whereas exhaust gases contained large amounts of chemical exergy. Casas-Ledón et al. [23] studied hydrogen production from ESR considering based on the first and second laws of thermodynamics. They evaluated the exergy efficiency of the system experimentally at different operational conditions (pressure, temperature, and S/C ratio) considering the unused and destructed exergy during the ESR process. They concluded that the exergetic efficiency of the ESR system was a function of temperature and S/C ratio, while no effect of pressure on exergy efficiency was observed. A comprehensive exergy analysis of the different types of ethanol reforming processes (ESR, POX and ATR) based on a model in Aspen Plus was performed by Khila et al. [19]. The same formulation as Casas-Ledón et al. [23] was used by Khila et al. and they used Aspen Plus software to calculate the exergy of the inlet and outlet streams at selected operational conditions, according to hydrogen production per mole of inlet ethanol. An exergy efficiency of $70 \%$ was claimed for the ESR process, considering total hydrogen production via ESR as the main product. In another study, Tippawan et al [24] employed the first and second law of thermodynamics to evaluate energy and exergy performance of a modelled ethanol reforming system in connection with a solid oxide fuel cell (SOFC) with a similar formulation as Casas-Ledón et al. [23] and Khila et al [25]. They studied ESR, partial oxidation (POX), and autothermal reforming (ATR) processes as the reforming sections for hydrogen production, and the best efficiency of the system (reforming+SOFC) was stated equal to $60 \%$ when ESR was used as the reformer unit. Finally, Hedayati et al. [26] reported exergetic evaluation of the ESR process in a staged membrane reactor based on experimental results. They considered only pure hydrogen as the desired product. It was reported that a big share of exergy is destroyed due to the irreversibility of reforming reactions and heat losses.

In this work, we present energy and exergy analysis of the ESR process in a catalytic membrane reactor (CMR) containing $\mathrm{Pd}-\mathrm{Ag}$ membranes sandwiched by $\mathrm{Pd}-\mathrm{Rh} / \mathrm{CeO}_{2}$ catalyst to produce pure hydrogen (no sweep gas). The exergy evaluation of the system is based on the experimental 
results. The novelty of this work lies in the application of exergy analysis to evaluate the ESR process in a packed bed CMR configuration based on experimental results and observations.

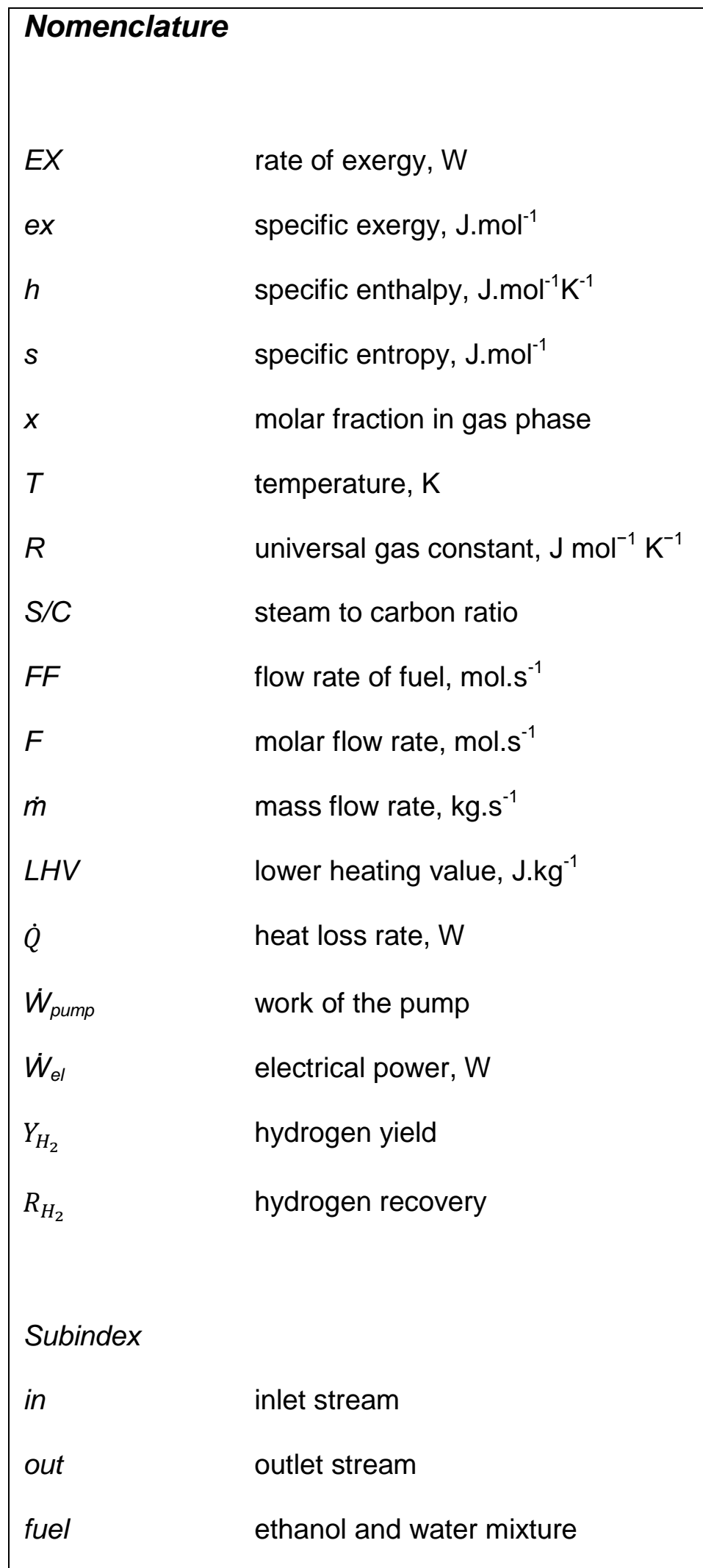




\begin{tabular}{|ll|}
\hline H2.perm & permeated hydrogen \\
H2.total & ethanol \\
& total hydrogen production \\
Greek Letters & \\
$\eta_{\text {thermal }}$ & thermal efficiency \\
$\varepsilon$ & standard chemical exergy, ${\mathrm{J} . \mathrm{mol}^{-1}}^{-1}$ \\
$\eta_{\text {ex }}$ & exergy efficiency \\
& \\
\hline
\end{tabular}

\section{Material and methods}

\subsection{Experimental}

The $\mathrm{Pd}-\mathrm{Rh} / \mathrm{CeO}_{2}$ catalyst $(0.5 \% \mathrm{Pd}-0.5 \% \mathrm{Rh})$ was deposited over cordierite pellets of about $1-3$ $\mathrm{mm}$ following the procedure described by López et al. [27]. The laboratory setup used for the ESR experiments (fuel reformer) consisted essentially of a fuel tank, a liquid pump, a CMR, a pressure transducer and a condenser. A detailed description of the reformer setup can be found in [26].

The heating plate was controlled by an electronic controller (Fuji PXR4), provided the temperature measurement registered by a k-type thermocouple which was in close contact with the reactor wall. The reactor was sandwiched between a $22 \mathrm{~mm}$ of glass wool aiming to thermal insulation. A HPLC pump (Knauer) was used to pump the water-ethanol mixture (fuel) and to keep the pressure. A backpressure regulator (Swagelok), which was regulated by means of a computer program, adjusted the retentate pressure. No pressure regulation was implemented on the permeate side (pure hydrogen outlet), so the permeate side pressure was kept automatically at ambient pressure. Besides, no sweep gas was used so pure hydrogen was obtained at atmospheric pressure. 
The reactor was 10 in. tall and $1 \mathrm{in}$. in diameter. There were four $\mathrm{Pd}-\mathrm{Ag}$ membrane tubes highly selective to hydrogen inside the reactor; each one $3 \mathrm{in.}$ tall and $1 / 8 \mathrm{in.}$ diameter in order to separate hydrogen. The membrane tubes consisted of $\mathrm{Pd}-\mathrm{Ag}$ (30 $\mu$ m layer) supported on porous stainless steel (PSS) provided by REB Research \& Consulting, MI, USA [28], accounting for 30.4 $\mathrm{cm}^{2}$ total active membrane area. The reactor was filled with 25 grams of the catalyst (cordierite plus $\mathrm{Pd}-\mathrm{Rh} / \mathrm{CeO}_{2}$, containing $0.34 \mathrm{~g}$ of $\mathrm{Pd}-\mathrm{Rh} / \mathrm{CeO}_{2}$ ) so that the metallic membranes were fully covered. The composition of the non-condensable portion of the outlet gas (retentate) was analyzed using an online Gas Chromatograph (Agilent 3000A MicroGC using MS $5 \AA$, PlotU and Stabilwax columns.)The scheme of the experimental setup and the CMR is presented in Fig. 1.

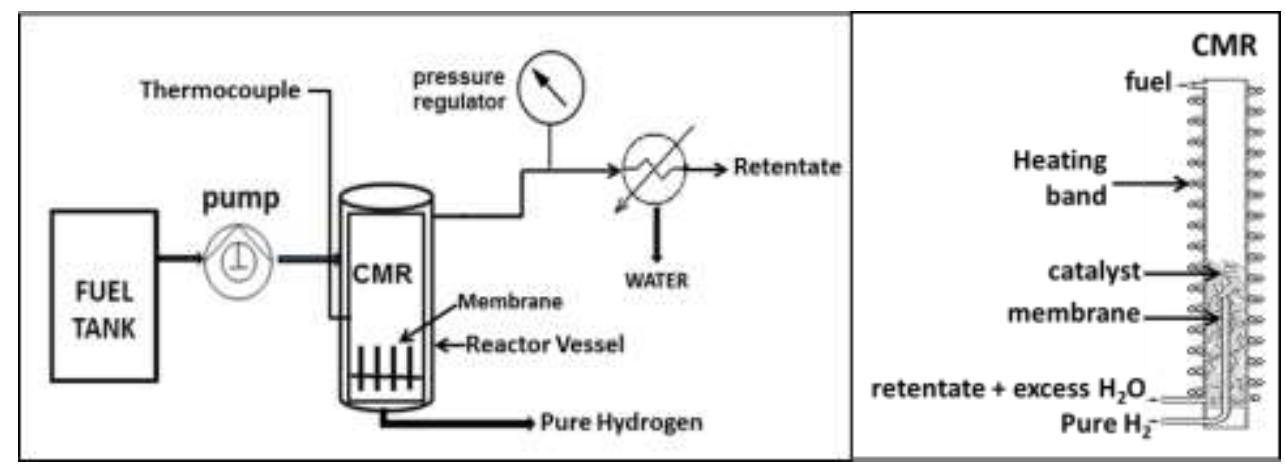

Fig. 1: Scheme of the catalytic membrane reactor (CMR)

The operating conditions of the experiments are summarized in table 1. A mixture of pure ethanol and distilled water at known molar ratios was used to resemble bioethanol. S/C ratio (S/C) is the measure of the molar ratio between water and ethanol in the fuel blend.

Table 1: Experimental conditions

\begin{tabular}{lr}
\hline Temperature (K) & $873-923$ \\
Pressure (bar) & $4-12$ \\
Fuel flow rate $(\boldsymbol{\mu l} / \mathrm{min})$ & $50-100$ \\
S/C & $1.6-3$ \\
WHSV $\left(\mathbf{h}^{-1}\right)$ & $2.4-6.9$
\end{tabular}


The pure hydrogen production rate is considered as the main point of evaluation of the CMR system. Factors such as hydrogen yield $\left(\mathrm{Y}_{\mathrm{H}_{2}}\right)$ and hydrogen recovery $\left(\mathrm{R}_{\mathrm{H}_{2}}\right)$ were selected to evaluate the performance of the CMR.

$Y_{H_{2}}=\frac{F_{H 2 . p e r m}}{6 \times F_{E t O H}}$

$R_{H_{2}}=\frac{F_{H 2 . p e r m}}{F_{H 2 . t o t a l}}$

Where $F_{\mathrm{H} 2 \text {. perm, }} \mathrm{F}_{\mathrm{EtOH}}$, and $\mathrm{F}_{\mathrm{H} 2 \text {. total }}$ are pure hydrogen permeation rate, ethanol flow rate, and total hydrogen production rate, respectively, in $\mathrm{mol} / \mathrm{s}$. Total hydrogen production included the permeated hydrogen and the hydrogen content of the retentate gas. $\mathrm{F}_{\mathrm{H} 2 \text {. perm }}$ was directly measured by a mass flow meter (Bronkhorst F-111B).

\subsection{Exergy analysis}

The traditional method of process performance evaluation based on the first law of thermodynamics is based on the lower heating value (LHV) of the inlet and outlet streams, plus the amount of work or heat provided to run the process. Thermal efficiency of the reformer system is defined as [25,26]:

$\eta_{\text {Thermal }}=\frac{\dot{m}_{\text {retentate }} \times L H V_{\text {retentate }}+\dot{\mathrm{m}}_{\text {pure hydrogen }} \times L H V_{\text {hydrogen }}}{\dot{\mathrm{m}}_{E t O H} \times L H V_{E t O H}+\dot{\mathrm{w}}_{\text {pump }}+\dot{Q}}$

$\dot{\mathrm{W}}_{\text {pump }}$ is the work of the pump. In this work, the work of the pump is neglected. $\dot{\mathrm{Q}}$ represents the rate of heat losses and the required energy to run ESR process in the CMR. Heat losses account for the heat released to the environment through the reactor wall, products cooling down, and water condensation. The reactor wall was considered as a stainless steel cylinder, transferring heat to the reference environment. To calculate the heat loss at different operating conditions, reactor wall temperature (in contact with air) was measured by means of a K-type thermocouple. The reactor vessel is a cylindrical stainless steel of $1 \mathrm{~mm}$ thickness in which the heart reactor is 
sandwiched between a $22 \mathrm{~mm}$ thick layer of glass wool (heat transfer coefficient $\mathrm{K}=0.04 \mathrm{~W} / \mathrm{m}$. K).

The catalytic zone is a stainless steel cylinder with the height of $67 \mathrm{~mm}$ and periphery of $280 \mathrm{~mm}$, accounting for $0.019 \mathrm{~m}^{2}$ area. The heat transfer coefficient of the $1 \mathrm{~mm}$ stainless steel wall was assumed infinite. The axial temperature gradients are neglected in this work and it is assumed that the catalyst bed and the membrane are kept at the set point reaction temperature (873 or $923 \mathrm{~K}$ ). The required heat for the evaporation and heating up the reactants was calculated according to the fuel flow rate and $\mathrm{S} / \mathrm{C}$ ratio of each experiment. The heat required for the reforming reactions also was calculated based on the progress of each of the chemical reactions (eq. 2-4) using the retentate composition.

It is assumed that the reactants enter the system at reference conditions and products are released to the same environment. In this work, the reference conditions are defined as $T_{0}=$ 298.15 $\mathrm{K}$ and $P_{0}=1,013$ bar. The scheme of the system under study is shown in Fig. 2.

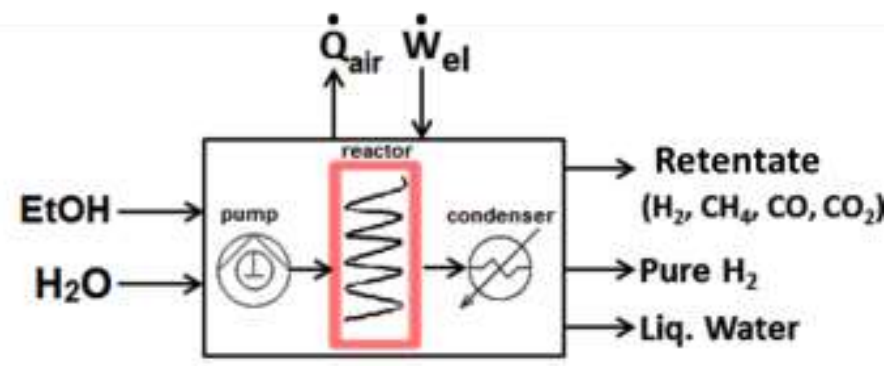

Fig. 2: Scheme of the boundary of the reformer system

$\dot{\mathrm{Q}}_{\text {air }}$ represents the heat loss rate. In fact, this heat in the form of exergy is a part of the inlet exergy stream $\left(\mathrm{W}_{\mathrm{el}}\right)$ which is released to the environment as unused exergy. $\dot{\mathrm{W}}_{\mathrm{el}}$ represents the electrical input of the system used by the heating band to provide the reactor with required heating. In this study, the work of the pump is neglected in exergy and energy evaluations. In this case, the required exergy is limited to the exergy lost via heat losses (reactor wall + products cooling process) and the required exergy to run the CMR; therefore, $\mathrm{W}_{\mathrm{el}}$ is replaced by the required heat for the ESR process. The required exergy to run ESR in the CMR is obtained via eq.XXX:

$E X_{\text {required }}=h-h_{0}-T_{0}\left(s-s_{0}\right)$ 
$\mathrm{h}$ and s are the specific enthalpy and specific entropy of ethanol or water at reaction (reactor) conditions. The subscript ' 0 ' denotes the reference conditions. The same equation was used to calculate the heat released to the environment when ESR products were cooled down from the reaction temperature to the reference temperature.

Exergy efficiency is calculated based on exergy destruction and unused exergy, as a function of the exergy rate of the inlet and outlet streams. This formulation has been repetitively used by different researchers $[23,25,26,29]$. Exergy destruction rate is defined as:

$E X_{\text {destruction }}=E X_{\text {in }}-E X_{\text {out }}$

Where $E X_{\text {in }}$ and $E X_{\text {out }}$ are the exergy rates of the inlet and outlet streams. Therefore, $E X_{\text {in }}$ represents the exergy rate of inlet fuel, i.e. ethanol (with its specific exergy ex $_{\text {fuel }}$ ), plus the required exergy rate for the ESR process including heat losses $\left(\mathrm{EX}_{\dot{\mathrm{W}}_{\mathrm{el}}}=\dot{\mathrm{W}}_{\mathrm{el}}\right)$, and $\mathrm{EX}$ out denotes the exergy rate of pure hydrogen stream (ex-perm), plus the retentate gases exiting the reactor (ex $\left.\mathrm{x}_{\text {retentate }}\right)$ :

$E X_{\text {in }}=F_{\text {EtOH }}$ ex $x_{\text {fuel }}+\dot{\mathrm{W}}_{\mathrm{el}}$

$E X_{\text {out }}=F_{H 2 . p e r m}$ ex $x_{H 2 . p e r m}+F_{\text {retentate }}$ ex retentate

The condensed water is considered to have zero exergy value. The rate of unused exergy is calculated as:

$E X_{\text {unused }}=E X_{\text {destruction }}+E X_{\text {retentate }}$

Where $\mathrm{EX}_{\text {retentate }}$ is equal to the exergy rate of the retentate gas. In this work, the exergy of the pure hydrogen stream is considered as useful part of exergy. Accordingly, the fraction of hydrogen in the retentate gas (not permeated) is not taken into account as the main product. Finally, the exergy efficiency of the ESR process is given by equation 12 :

$$
\eta_{\text {ex }}=1-\frac{E X_{\text {unused }}}{E X_{\text {in }}}
$$


The specific exergy content of each specie (ex) in each stream consists of physical exergy $\left(\mathrm{ex}_{\text {physical }}\right)$, chemical exergy (ex $\left.\mathrm{x}_{\text {chemical }}\right)$, and mixing exergy (ex $\left.\mathrm{x}_{\text {mixing }}\right)$ :

$e x=e x_{\text {physical }}+e x_{\text {chemical }}+e x_{\text {mixing }}$

Physical exergy (ex $x_{\text {physical }}$ ) is the maximum obtainable work produced when a stream is brought from the actual conditions $(T, P)$ to the reference conditions $\left(P_{0}, T_{0}\right)$ and is defined as $[18,30]$ :

exphysical $=h-h_{0}-T_{0}\left(s-s_{0}\right)$

$\mathrm{h}$ and s are the specific enthalpy and specific entropy of the substance at actual (reaction) conditions, and $h_{0}$ and $s_{0}$ are the specific enthalpy and specific entropy of the substance at reference conditions, respectively. The dependency of the physical exergy on enthalpy and entropy highlights two features. First, exergy is a function of the state of the matter, and second, each matter is considered independently in a stream.. Both features result in a more precise idea on the performance of a thermal system. To calculate the values of enthalpy and entropy, NASA polynomials (Chemkin polynomial coefficients) $[30,31]$ for temperatures below $1000 \mathrm{~K}$ were applied.

Chemical exergy originates from the difference between the chemical potentials when a substance is changed at reference conditions to the chemical equilibrium state with the concentrations of components. In this work, the chemical exergy of each specie was calculated using the standard chemical exergy table given by Bejan model II [17]. Chemical exergy occasionally is reported as a sum of two terms, i.e. the standard chemical exergy plus a logarithmic term as a function of the fraction of each substance in a mixture [23,24]:

$e x_{\text {chemical }}=x_{i} \varepsilon_{i}+R T_{0} x_{i} \operatorname{Lnx} x_{i}$

Where $x_{i}$ is the fraction of any species in the mixture of gases, $\varepsilon_{i}$ is the standard chemical exergy of the species, and $R$ is the universal gas constant. The second term, as is always negative, can be 
ascribed to the exergy of mixing. Exergy of mixing is the entropy generated when pure substances are mixed and is given by equation 16 [18]:

ex mixing $=x_{i} R T_{0} \operatorname{Ln} x_{i}$

However, the value of mixing exergy is normally negligible in front of standard chemical exergy [32]. A comprehensive discussion on various types of exergy calculation is given by Sato [18] and

Hinderink et al. [32]. Similar definitions have been reported in some studies which are based on the entropy difference between the mixture of substances and the pure components (which exist in the mixture) individually $[25,32]$. In this work, all three types of exergy were considered for each species in the inlet and outlet streams. The molar flow rate of reactants and products obtained during the experimental work were used for evaluation of the exergy flow of each stream.

\section{Results and discussion}

\subsection{Experimental results}

Based on the experimental observations and following the reported results in the literature $[10,27]$, the only species detected in the retentate stream by the $\mathrm{GC}$ are $\mathrm{CH}_{4}, \mathrm{CO}_{2}, \mathrm{CO}$, and $\mathrm{H}_{2}$. No ethanol was detected in the retentate stream, proving complete conversion of ethanol. The condensed liquid was odorless, colorless, and containing only condensed water.

Prior to the experiments at high pressure, the performance of the CMR was checked at atmospheric pressure in terms of the selectivity of the ESR products. The selectivity of gases at 873 and $923 \mathrm{~K}, \mathrm{FF}=100 \mu \mathrm{l} / \mathrm{min}$, and $\mathrm{S} / \mathrm{C}=1.6,2$, and 3 is given in Fig.XXX. 

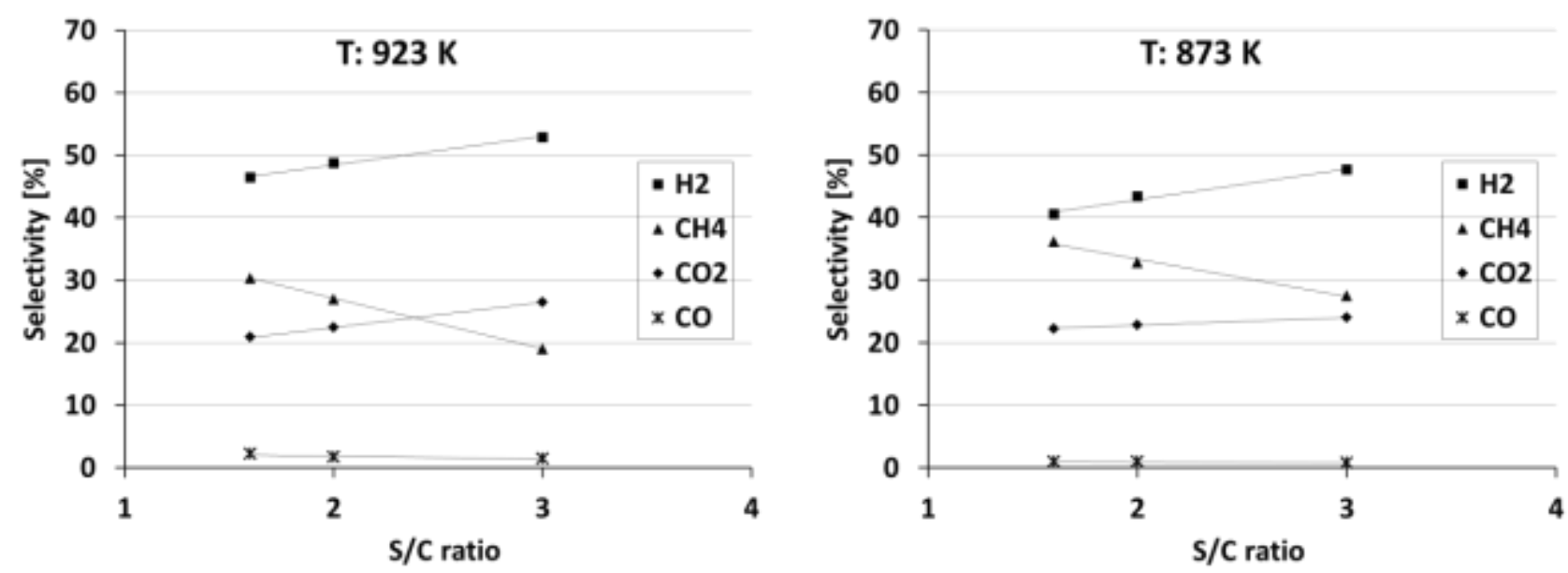

Figure $\mathrm{XXX}$ - The selectivity of the ESR products at atmospheric pressure

The selectivity of hydrogen increased with $\mathrm{S} / \mathrm{C}$, while the methane selectivity decreased. This is attributed to the availability of excess water at higher S/C ratio, which promoted the MSR reaction. The increasing trend of $\mathrm{CO}_{2}$ proved the reaction promotion at higher $\mathrm{S} / \mathrm{C}$ ratio. Very small amount of $\mathrm{CO}$ was detected, which was considered as an advantage of the CMR configuration specially at $923 \mathrm{~K}$ where the temperature is not in favor of the WGS reaction. The slightly higher selectivity of $\mathrm{CO}$ at $923 \mathrm{~K}$ is ascribed to the exothermic nature of the WGS reaction.

Both hydrogen production and its permeation through the membrane depend on temperature. On one hand, hydrogen permeation through the membrane is a temperature activated phenomena and, on the other hand, the progress of methane steam reforming (MSR) as the dominant hydrogen producing reaction is favored naturally with temperature as it is an endothermic chemical reaction (eq. 4). This behavior is shown in Fig. 3 at constant S/C ratio and fuel flow rate (FF) at 873 and $923 \mathrm{~K}$. 


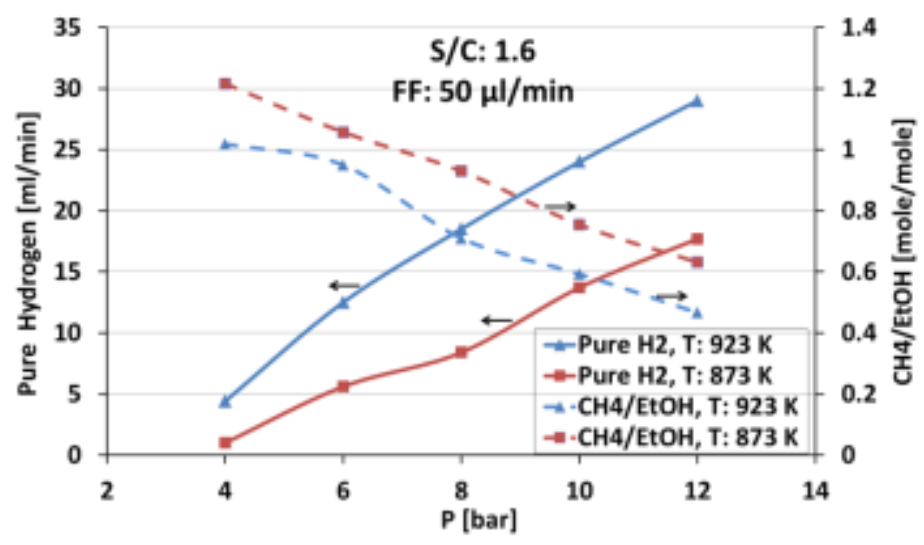

Fig. 3: Effect of temperature and pressure on the permeated hydrogen and on the methane production ratio. FF represents the fuel flow rate in $\mu \mathrm{l} / \mathrm{min}$.

Pure hydrogen production gets doubled as the temperature increases by $50 \mathrm{~K}$ from $873 \mathrm{~K}$ to 923 $\mathrm{K}$, at constant $\mathrm{S} / \mathrm{C}$ ratio and fuel flow rate and $\mathrm{P}>6$ bar. At $\mathrm{P}<6$ bar, traces of methanation are seen $\left(\frac{\text { mole } \mathrm{CH}_{4}}{\text { mole EtOH }}>1\right)$. This phenomenon is caused by operating at high pressure where the MSR reaction (eq. 4) is pushed backward according to Le Chatelier's Principle. At pressures greater than 6 bar, hydrogen permeation is improved as a result of higher partial pressure of hydrogen around the membrane (Sieverts' law). Therefore, MSR and WGS reactions are promoted, as the catalyst is available around the membrane to compensate for the removed product (permeated hydrogen). This is an evident result of the shift effect in CMR configuration leading to the promotion of the reforming reactions. In the light of the shift effect, it is obvious that as more methane is converted, more hydrogen is produced and therefore is permeated as pure hydrogen. Temperatures lower than $873 \mathrm{~K}$ are not tested because the permeation of hydrogen is very small.

Hydrogen permeation together with mol of permeated hydrogen per mol of ethanol in the feed at two different fuel flow rates are shown in Fig. 4. At higher pressures the gap between the two flow rates is widened as a result of higher rates of hydrogen permeation through the membrane. It is proved that the catalyst around the membrane is able to compensate for the permeating hydrogen by simultaneous hydrogen production. Therefore, in case of availability of more fuel, relatively more hydrogen is permeated. 


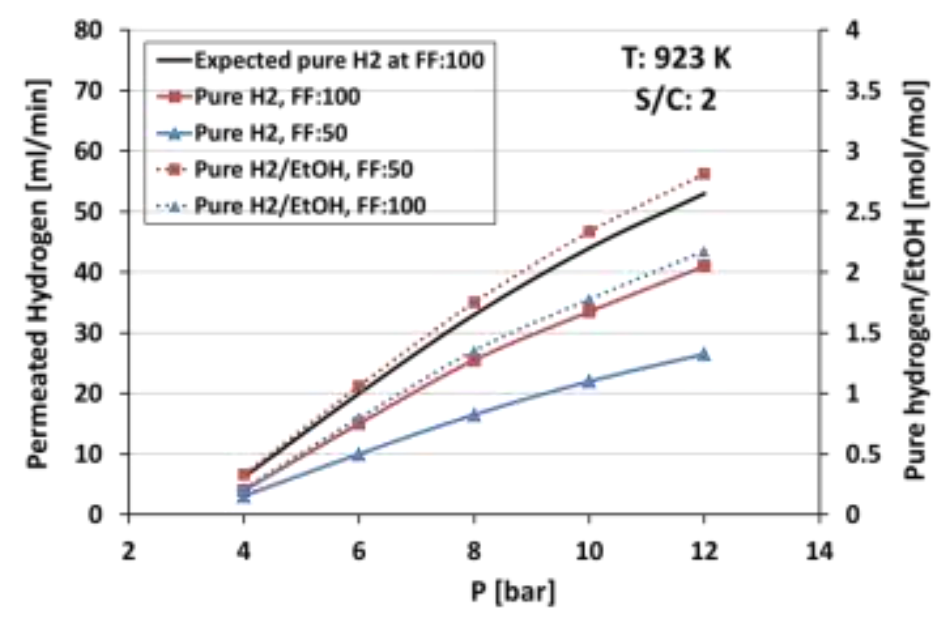

Fig. 4: Effect of fuel flow rate (FF) on pure hydrogen flow rate

At $\mathrm{FF}=100 \mu \mathrm{l} / \mathrm{min}$, the pure hydrogen permeation rate is not exactly doubled compared to the one at $F F=50 \mu l / m i n$ since not all the converted hydrogen can permeate through the membrane while the inlet ethanol gets doubled. As shown in figure 4 , the number of moles of pure permeated hydrogen per mol of inlet ethanol is higher at lower fuel flow rate.

As stated by Sieverts' law, the driving force for pure hydrogen permeation through a membrane is proportional to the square roots of partial pressures of hydrogen at both sides of the membrane. The higher the operating pressure, the higher the partial pressure of hydrogen around the membrane. In other words, the special configuration of the reactor results in overcoming the negative effect of pressure on the reforming reaction.

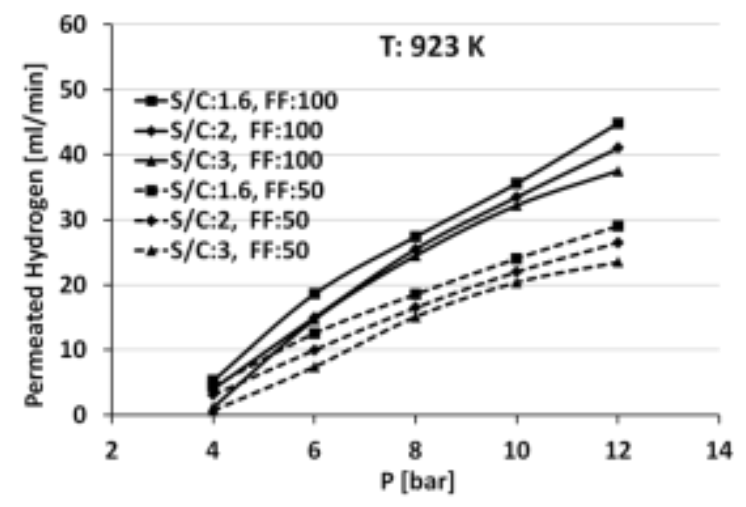

Fig. 5: Pure hydrogen production at different fuel flow rates and S/C ratios. FF represents the fuel flow rate in $\mu \mathrm{l} / \mathrm{min}$. 
Figure 5 shows the results concerning the effect of the $\mathrm{S} / \mathrm{C}$ ratio. The pure hydrogen flow rate declines with S/C ratio because less ethanol as the source of hydrogen is fed into the CMR at higher S/C ratios. Besides, the excess water results in a lower hydrogen partial pressure inside the reactor. Pressures higher than 12 bar and temperatures higher than $923 \mathrm{~K}$ are not tested because of the experimental setup limitations.

Hydrogen yield is a well-known indicator of the performance of hydrogen producing systems. According to equation 5, hydrogen yield refers to pure hydrogen, which can reach up to 1 , if 6 moles of pure hydrogen are obtained and permeated through the membrane per 1 mole of inlet ethanol (ideal conditions, i.e. complete conversion of ethanol to $\mathrm{CO}_{2}$ and $\mathrm{H}_{2}$ ).

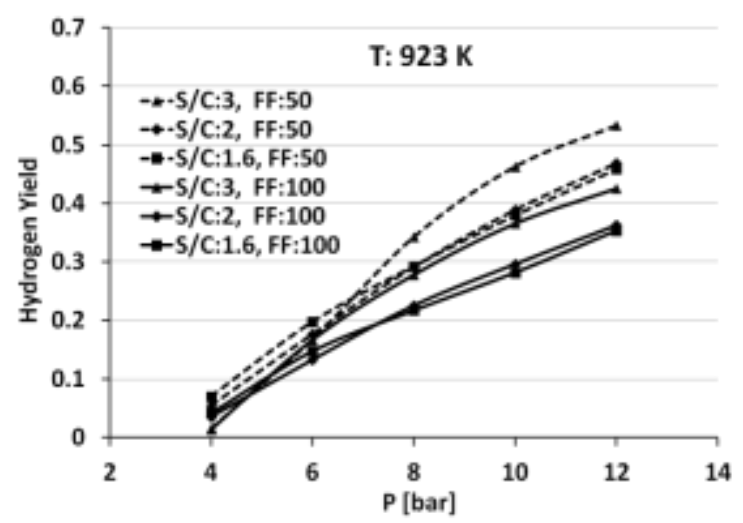

Fig. 6: Hydrogen yield obtained at different fuel flow rates and S/C ratios. FF represents the fuel flow rate in $\mu \mathrm{l} / \mathrm{min}$.

According to the Sieverts' law, hydrogen yield increases with pressure (Figure 6). However, the influence of the $\mathrm{S} / \mathrm{C}$ ratio on hydrogen yield is not straightforward; on one hand high $\mathrm{S} / \mathrm{C}$ values promote the reforming process but, on the other hand, the excess water results in lower hydrogen partial pressure, which results in lower hydrogen permeation (equation 5).

At complete ethanol conversion, hydrogen recovery is a measure of the ability of the system to produce pure hydrogen. This refers essentially to the membrane performance and obviously high values are required due to the high cost of the Pd-Ag membranes. The hydrogen recovery as a function of pressure is presented in Fig. 7. 

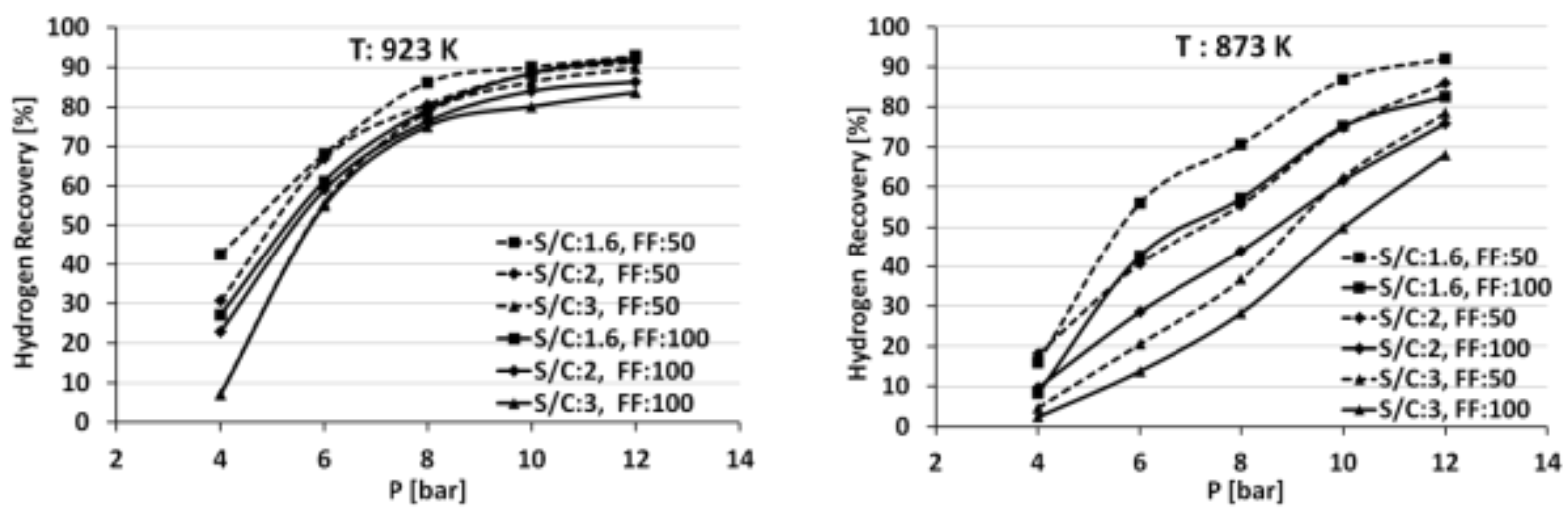

Fig. 7: Hydrogen recovery at different experimental conditions. FF represents the fuel flow rate in $\mu \mathrm{l} / \mathrm{min}$.

As expected, hydrogen recovery is favored at lower $S / C$ values since the partial pressure of hydrogen in the reactor is higher (less excess water) and, hence, the permeation through the membrane is improved according to the Sieverts' law. In addition, at a lower fuel flow rate the contact time increases and the permeation of hydrogen is favored. At $923 \mathrm{~K}$, hydrogen recovery increases sharply up to 8 bar and after that the trend becomes less sharp which is due to the hydrogen fraction in the retentate side. However, at pressures greater than 8 bar, the thermodynamics are unfavorable to the reforming reactions resulting in almost constant partial pressure of hydrogen inside the reactor. On average, for every 2 bar increase in pressure, the pure hydrogen production increases by 0.5 mole/mole ethanol in the feed. Accordingly, the fraction of hydrogen in the retentate side decreases with pressure, which is attributed to the fact that more hydrogen is permeated (recovered) through the membrane. Pure hydrogen production rate and hydrogen fraction in the retentate side as a function of pressure are illustrated in Fig. 8.

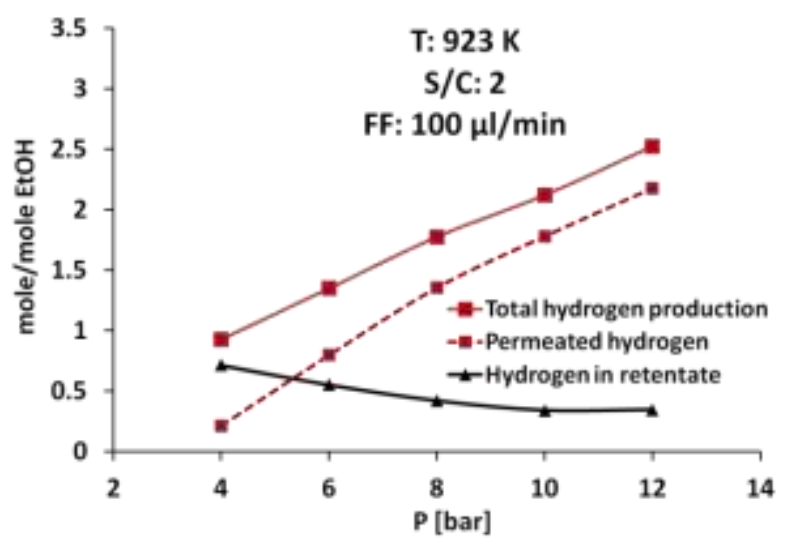


Fig. 8: Hydrogen flow rate in different streams. FF represents the fuel flow rate in $\mu \mathrm{l} / \mathrm{min}$.

Hydrogen permeation rate and hydrogen recovery values presented in this study are comparable to the literature, where a CMR or noble metal based catalysts have been used for ESR aiming to pure hydrogen production. A comparison between the similar works is given in table $\mathrm{XXX}$.

\begin{tabular}{|c|c|c|c|c|c|c|c|}
\hline Ref. & Catalyst & $\mathrm{T}(\mathrm{K})$ & $\mathrm{P}$ (bar) & $\mathrm{S} / \mathrm{C}$ ratio & $\begin{array}{c}\text { Hydrogen } \\
\text { yield }\end{array}$ & $\begin{array}{l}\text { Hydrogen } \\
\text { recovery (\%) }\end{array}$ & $\begin{array}{c}\text { Sweep } \\
\text { gas }\end{array}$ \\
\hline This work & $\begin{array}{c}0.5 \% \mathrm{Pd}-0.5 \% \\
\mathrm{Rh} / \mathrm{CeO} 2\end{array}$ & $873-923$ & $1-12$ & $1.6-3$ & $0-0.55$ & $10-90$ & No \\
\hline [27] & $\begin{array}{c}0.5 \% \mathrm{Pd}-0.5 \% \\
\mathrm{Rh} / \mathrm{CeO} 2\end{array}$ & $823-923$ & $1-11$ & $1-3$ & $1.5-2.5$ & $30-70$ & No \\
\hline [33] & Ru/Al2O3 & $473-673$ & $1.2-2$ & $4.2-6.5$ & $0.45-0.8$ & $66-100$ & Yes \\
\hline [34] & $\mathrm{Ru} / \mathrm{Al} 2 \mathrm{O} 3$ & $573-673$ & 1.3 & $1.5-4.5$ & $0.1-0.55$ & $<22$ & Yes \\
\hline [35] & Rh/La2O3-SiO2 & $773-823$ & 1 & $1.5-5$ & $0.1-0.45$ & $20-80$ & Yes \\
\hline [36] & $\mathrm{Ru} / \mathrm{Al} 2 \mathrm{O} 3$ & $673-773$ & $2-3.6$ & 5.5 & - & $10-30$ & Yes \\
\hline
\end{tabular}

The superior performance of the presented setup is attributed not only to the robust reactivity of the $0.5 \% \mathrm{Pd}-0.5 \% \mathrm{Rh}$ catalyst, but also to the high oxygen storage capacity (OSC) of $\mathrm{CeO}_{2}$ at high temperatures [37].

\subsection{Exergy analysis}

The optimization of the reforming system not only depends on the improvement of pure hydrogen permeation rate, but also on the thermodynamic efficiencies. Thermodynamic evaluation results in a better understanding of the effect of the operating conditions on the performance of the reforming system. Pure hydrogen production gets higher naturally with the fuel flow rate, as discussed earlier. This is in agreement with the thermal efficiency, but not with exergy efficiency due to the 
criteria based on which the thermal and exergy efficiencies are defined thermal and exergy efficiency at $\mathrm{FF}=50$ and $100 \mu \mathrm{l} / \mathrm{min}$ are presented versus pure hydrogen permeation rate in figure $9 a$ and $b$, respectively. As more methane is produced at higher fuel flow rate, thermal efficiency is higher. But as less hydrogen is produced per mol of converted ethanol at higher fuel flow rate (see Fig. 4), the exergy efficiency decreases with fuel flow rate.
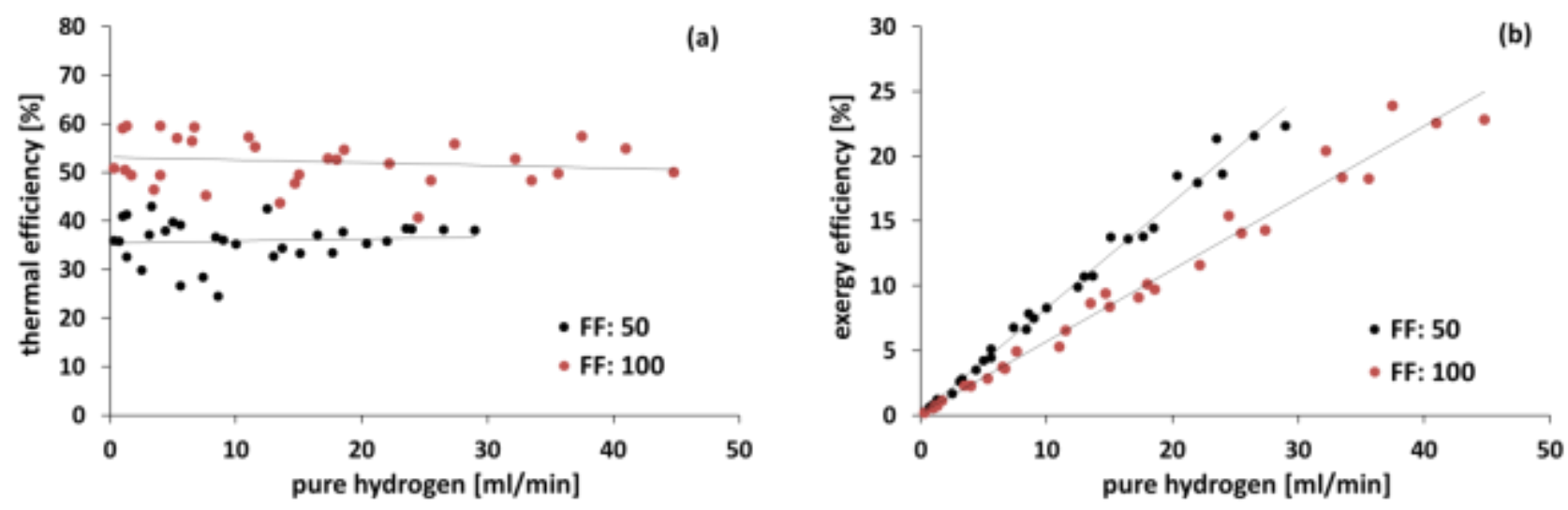

Fig. 9: Thermal efficiency (a) and exergy efficiency (b) vs pure hydrogen permeation rate

Apart from the fuel flow rate, the operating temperature and pressure are the key factors in high production rate of pure hydrogen, as discussed in the experimental section. As shown in figure 9a, almost the same magnitude of thermal efficiency is obtained at different pure hydrogen production rates, which correspond to the different operating conditions. Obviously, the performance of the reforming system cannot be explained precisely by means of thermal efficiency, bearing in mind that pure hydrogen is the product of this reforming system.

In the case of exergy efficiency, the effect of operating conditions, specially pressure, is clearly explained. The hidden effect of pressure can be seen as the driving force for hydrogen permeation is the difference between the partial pressures of hydrogen at the retentate and permeate sides (see Fig.4 and 5). The exergy efficiency linearly increases with pure hydrogen production (see Fig. 9b). The advantage of exergy evaluation over the thermal efficiency evaluation is clear since the effect of operating conditions can be explained by exergy evaluation. Figure $9 \mathrm{~b}$ states that the improvement of the reforming system depends on decreasing the irreversibility and losses of the 
reforming system at higher production rates of pure hydrogen. Accordingly, it is essential to study the effect of temperature, pressure, fuel flow rate, and $S / C$ ratio, on the exergy efficiency, together with the source of losses of this reforming system.

\subsubsection{Effect of operational conditions on exergy efficiency}

Pressure has a strong effect on exergy efficiency. As seen in Fig. 10, the best exergy efficiency is obtained at 12 bar, whatever the temperature.

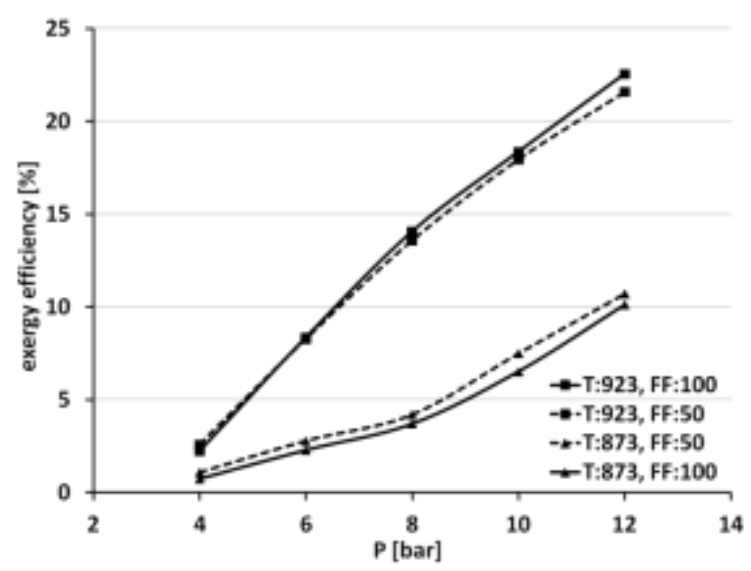

Fig. 10: Effect of pressure on exergy efficiency at $873-923 \mathrm{~K}$ and $\mathrm{S} / \mathrm{C}=2 \mathrm{FF}$ represents the fuel flow rate in $\mu \mathrm{l} / \mathrm{min}$.

Following the pure hydrogen permeation rate (Fig. 5), the highest exergy efficiency is reached at the highest pressure, which is in agreement with hydrogen production and hydrogen yield. The effect of temperature is seen in Fig. 10. At $873 \mathrm{~K}$ the system is not efficient, even at high pressure. This is ascribed to the important role of methane steam reforming (MSR) reaction, which produces the highest number of moles of hydrogen. This clearly demonstrates the importance of high temperature to reform methane and run the system efficiently. The effect of the fuel flow rate on the exergy efficiency is not noticeable.

The steam to carbon ratio $(\mathrm{S} / \mathrm{C})$ shows different effects on the reforming system at 873 and $923 \mathrm{~K}$. The exergy efficiency increases slightly with the S/C ratio at $923 \mathrm{~K}$, while an opposite effect is seen at $873 \mathrm{~K}$ (Fig. 11). This is explained considering the molar production rate of pure hydrogen per 
mole ethanol in the feed. At complete conversion of ethanol, the extent of the methane steam reforming reaction determines the hydrogen production rate and therefore the value and the trend of exergy efficiency as a function of the $\mathrm{S} / \mathrm{C}$ ratio. At $923 \mathrm{~K}$, the MSR reaction is promoted and more hydrogen is produced, as higher amount of water is available (higher $\mathrm{S} / \mathrm{C}$ ). at $873 \mathrm{~K}$, the dilution effect of excess water is dominant, so that the exergy efficiency declines with $S / C$ ratio.
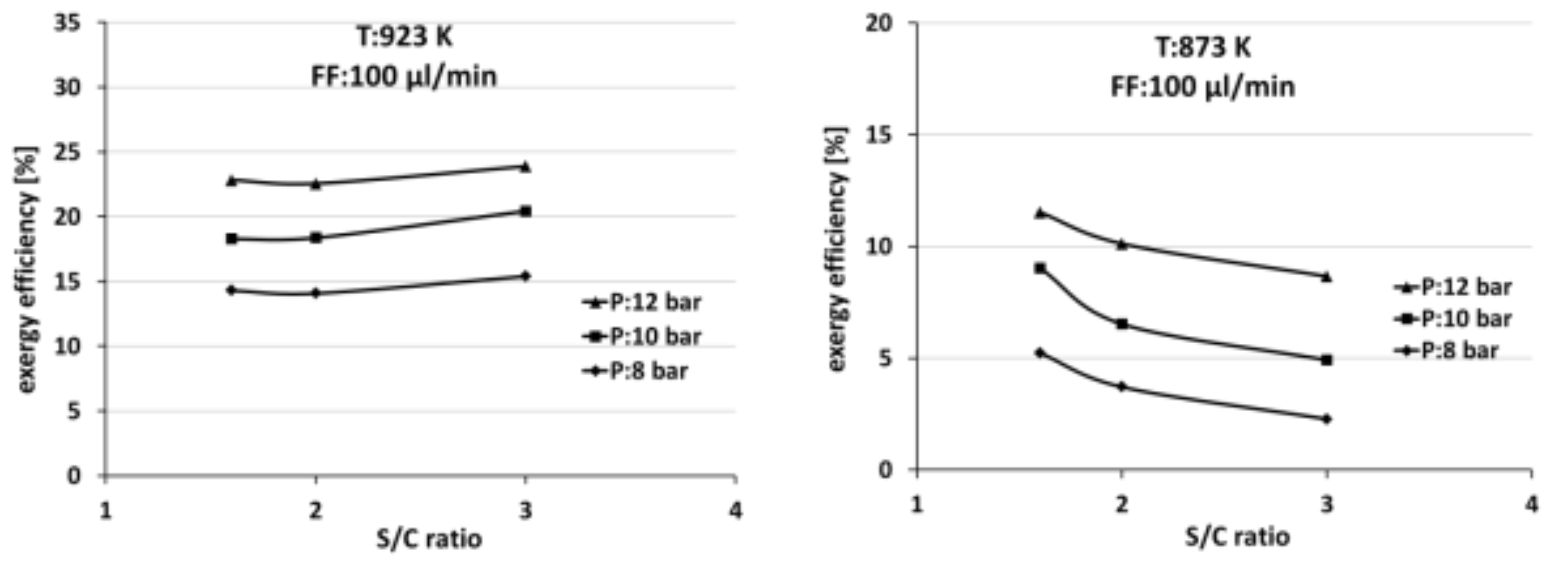

Fig. 11: Effect of S/C ratio on exergy efficiency

The comparatively lower values of the exergy efficiency obtained in this work in comparison with what has been reported in the literature $[19,20,24]$ are explained by taking into account that here we only consider the exergy content of pure hydrogen as the evaluation base (not the total hydrogen produced).

Thermal efficiency of the reforming system is between 30 and $60 \%$, depending on the operating conditions.

\subsubsection{Exergy efficiency improvement}

Analysis of the exergy content of each inlet/outlet stream leads to obtain a better understanding of the performance of the system and the feasibility to recover or decrease the exhaust or destructed exergy. The exergy destruction due to the irreversibility attributable to the reforming reactions lessens with $\mathrm{S} / \mathrm{C}$ ratio because there is less ethanol in the feed. Heat loss constitutes one of the 
major shares of exergy destruction accounting for $50 \%$ of the outlet exergy flow on average at $\mathrm{FF}=50 \mu \mathrm{l} / \mathrm{min}$. Another notable source of exergy loss is the retentate gas, which contains $\mathrm{CH}_{4}, \mathrm{CO}$, and not permeated $\mathrm{H}_{2}$. According to the evaluation, there is a considerable amount of exergy in the retentate gas that could be used for the ESR process. Since the system best performance is achieved at $923 \mathrm{~K}$ and 12 bar, the analysis of the system in terms of inlet/outlet exergy flows is done at these conditions. Figure 12 shows the comparison between the inlet and outlet exergy flows calculated at $923 \mathrm{~K}$ and 12 bar under different fuel flow rates and $\mathrm{S} / \mathrm{C}$ ratios.

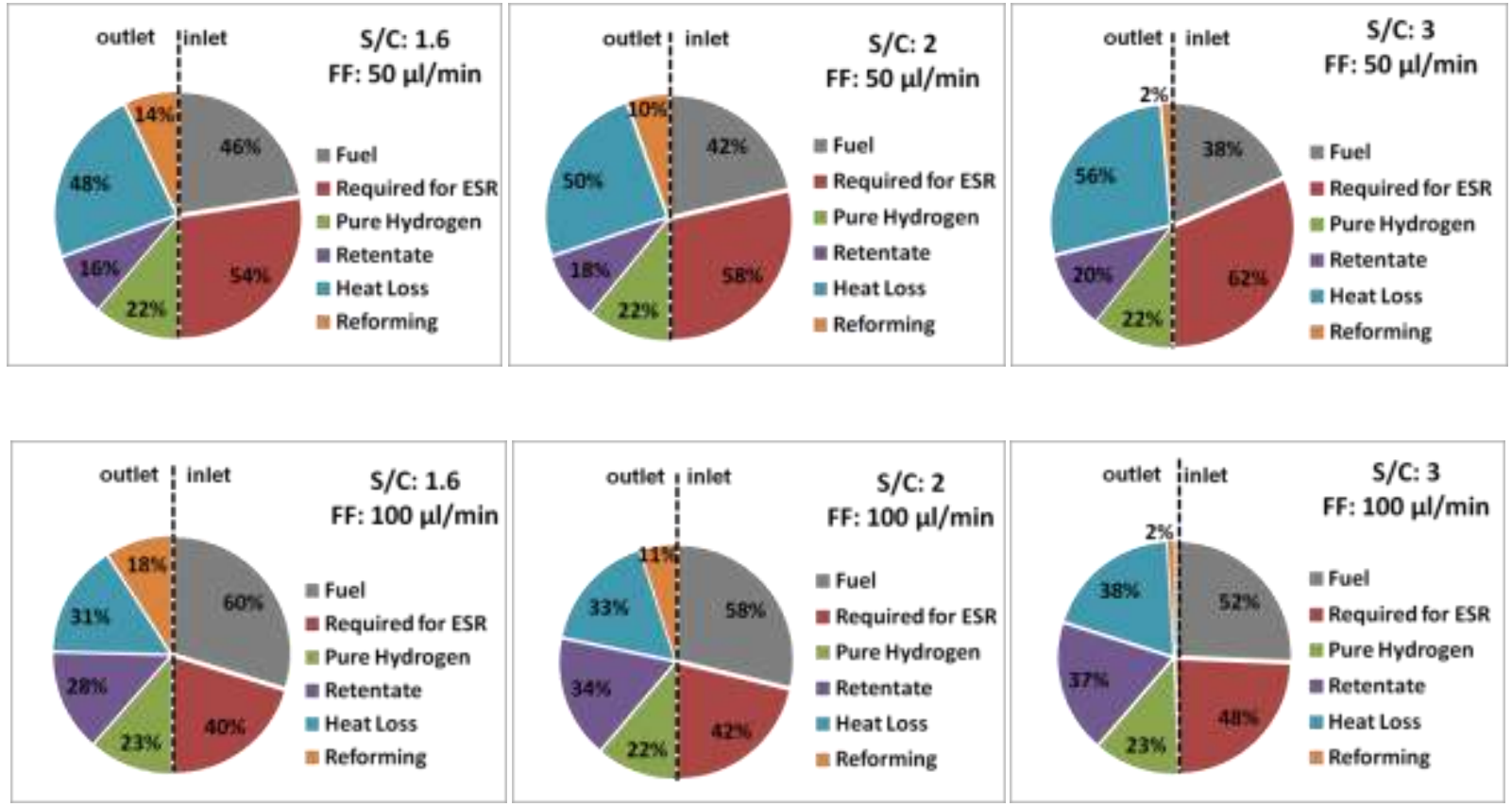

Fig. 12: Exergy flows at $923 \mathrm{~K}$ and 12 bar at various $\mathrm{S} / \mathrm{C}$ ratios. FF represents the fuel flow rate in $\mu \mathrm{l} / \mathrm{min}$.

The inlet stream consists of the exergy of the fuel and the required exergy for the CMR, which is the same as $\dot{\mathrm{W}}_{\mathrm{el}}$ in eq.9 (see also Fig 2.). At the outlet, the exergy of retentate (non-condensable products), pure hydrogen, and heat losses, are presented. Exergy of reforming represents the exergy destruction due to the irreversible chemical reforming reactions (The exergy of the condensing water is negligible). Exergy required for ESR means xxx. The exergy content of the retentate stream originates mainly from the presence of unconverted $\mathrm{CH}_{4}$ and unpermeated $\mathrm{H}_{2}$. As shown, heat loss and retentate gases are the major sources of exergy loss. Consequently, the 
exergy efficiency of the reforming system can be improved by insulation of the reactor and by recovering the retentate gas exergy content.

The combustion of the retentate gas is a clear source of energy to provide the required heat for the ESR reactor, which accounts for evaporation and heating up the reactants, the ESR reactions, and heat losses. In Fig. 13, the ratios of the exergy rate of the retentate ( $\left.E X_{\text {retentate }}\right)$ gas and the required exergy rate for the ESR reactor over the inlet exergy rate $\left(E X_{i n}\right)$ at $923 \mathrm{~K}$ are shown.
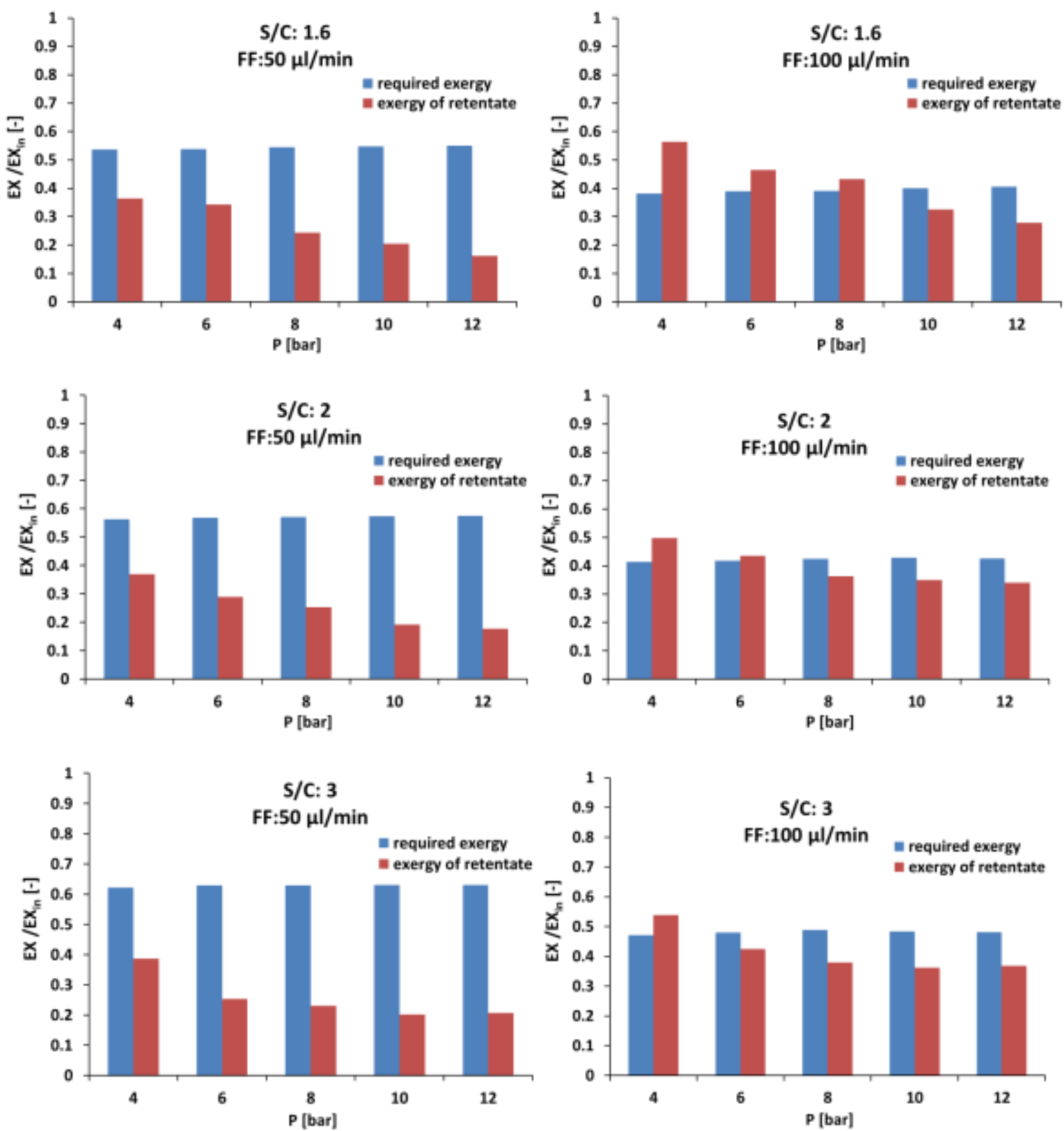
Fig. 13: Exergy rate of the retentate gas and required exergy rate over the exergy rate of the inlet vs. pressure for the ESR process at $T=923$

The exergy rate of the retentate gas is high enough to provide the reactor with a notable fraction (at $F F=50 \mu / / m i n$ ) or almost all (at $F F=100 \mu l / m i n$ ) of its required exergy at steady state conditions. The exergy rate of the retentate gas is significantly higher at $\mathrm{FF}=100 \mu \mathrm{l} / \mathrm{min}$ due to the high molar production rate of methane. Hence, the exergy efficiency is improved as the value of $\mathrm{W}_{\mathrm{el}}$ is reduced (see Fig. 2), so that at $923 \mathrm{~K}, 12 \mathrm{bar}, \mathrm{S} / \mathrm{C}=3$, and $\mathrm{FF}=100 \mu \mathrm{l} / \mathrm{min}$, the exergy efficiency increases by $14 \%$ (absolute value). The comparison between the values of exergy efficiency in case of utilization of the retentate gas at $923 \mathrm{~K}$ and 12 bar and different $\mathrm{S} / \mathrm{C}$ ratios is presented in table 2 .

Table 2: comparison of exergy efficiency in case of retentate gas utilization at $\mathrm{T}=923 \mathrm{~K}$ and $\mathrm{P}=12$ bar

\begin{tabular}{|ccccccc|}
\hline FF $[\mu \mathrm{l} / \mathrm{min}]$ & 50 & & & 100 & \\
\hline S/C ratio & 1.6 & 2 & 3 & 1.6 & 2 & 3 \\
\hline $\begin{array}{c}\text { Exergy efficiency } \\
{[\%]-\text { retentate }}\end{array}$ & 22 & 21 & 21 & 23 & 23 & 24 \\
not used & & & & & \\
\hline $\begin{array}{c}\text { Exergy efficiency } \\
{[\%] \text { - retentate }}\end{array}$ & 39 & 40 & 42 & 51 & 57 & 61 \\
used & & & & & \\
\hline
\end{tabular}

In the case of an insulated reactor ( $\dot{Q}_{\text {air }} \rightarrow 0$ ), the exergy efficiency is remarkably improved. If the reactor is insulated, the energy demand of the system is limited to the heat needed to run the system at a certain temperature. This heat is used for fuel evaporation and heating up to reaction temperature, and the reforming reactions. In the case of an insulated reactor, the exergy efficiency is increased by $5-25 \%$ absolute, depending on the operating conditions. At $923 \mathrm{~K}, 12 \mathrm{bar}$, and

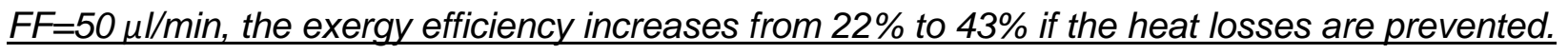


The exergy efficiency of the insulated system at similar conditions as in Fig.9 is illustrated in Fig.

14.

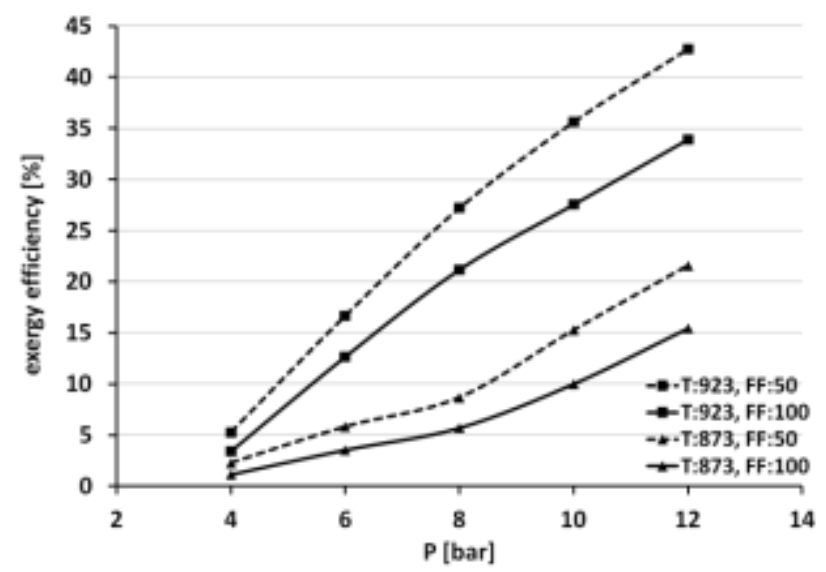

Fig. 14: Effect of pressure on exergy efficiency at 873-923 K, FF = 50-100 $\mu / / \mathrm{min}$, and $\mathrm{S} / \mathrm{C}=2$ for the insulated reactor

At pressures higher than 8 bar, and especially at $923 \mathrm{~K}$ the exergy efficiency is highly improved. In the case of the insulated reactor, the effect of the fuel flow rate is more obvious (see Fig. 10) which is attributed to the dominant effect of heat losses when the reactor is not insulated. Exergy efficiency is higher at $F F=50 \mu \mathrm{l} / \mathrm{min}$ because the pure hydrogen production rate does not double when the fuel flow rate does, as discussed before. The dependency of exergy efficiency on S/C ratio is clearer in an insulated reactor due to the dominant value of ethanol exergy in the inlet stream. The concentration of ethanol in the feed is lower at higher S/C ratio. The exergy efficiency of the insulated reactor system is presented in table 3.

Table 3: Exergy efficiency at $P=12$ bar and $F_{F}=50 \mu \mathrm{l} / \mathrm{min}$ for the insulated reactor

\begin{tabular}{|lcccccc|}
\hline $\mathbf{T}[\mathrm{K}]$ & & $\mathbf{8 7 3}$ & \multicolumn{3}{c|}{923} \\
\hline S/C ratio & 1.6 & 2 & 3 & 1.6 & 2 & 3 \\
\hline Exergy & 26 & 22 & 18 & 42 & 43 & 48 \\
efficiency [\%] & & & & & & \\
\hline
\end{tabular}

The opposite trend of the exergy efficiency is attributed to the MSR reaction promotion at $923 \mathrm{~K}$, as explained in Fig. 11. Following the trend of exergy efficiency, unused exergy is an obvious function 
of temperature and pressure when an insulated reactor is considered. The reason lies in the rate of pure hydrogen production and the presence of methane as the major component of the retentate. Methane production per mole of inlet ethanol decreases by $50 \%$ as pressure increases from 4 bar to 12 bar at $S / C=1.6$ (see Fig.3). At higher pressure, as less methane appears in the retentate stream, the exergy content of retentate is greatly decreased. The rate of unused exergy over the rate of inlet exergy $\left(E X_{\text {in }}\right)$ at different operating conditions is given in Fig. 15.
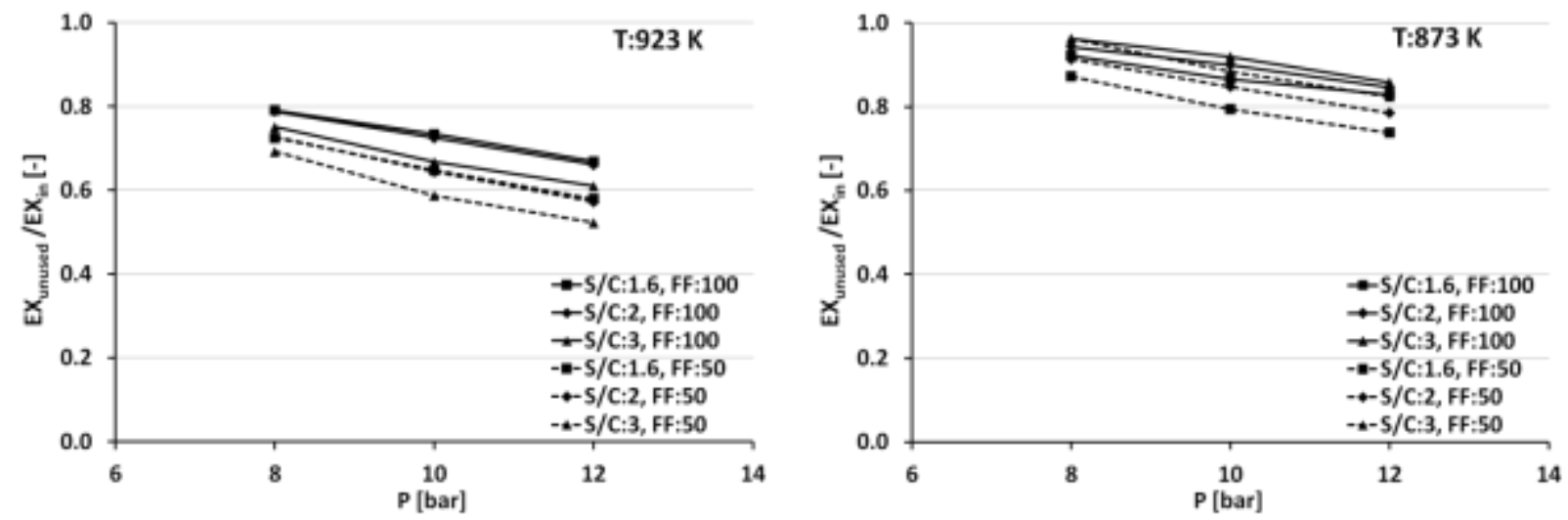

Fig. 15: Unused exergy rate over inlet exergy rate for the insulated reactor.

At $\mathrm{P}<8$ bar, hydrogen permeation rate is very low, resulting in huge amounts of reformed gases leaving the reactor as retentate stream. Hence, a huge share of inlet exergy is lost in the form of unused exergy (see eq. 7).

Thermal efficiency of the system in the case of insulation of the reactor is placed between $70-95 \%$ stating the ideal behavior of the reforming system. On the contrary, exergy efficiency - which reaches up to around $50 \%$ if the reactor is insulated, discloses inevitable irreversibility even when the reactor is insulated.

By utilization of the retentate gas in an insulated reactor, the exergy efficiency is increased drastically and is placed between $70-90 \%$, which is a high value compared to the reported works in the literature, bearing in mind that permeated pure hydrogen is considered as the only product of the reforming system. This result is expected since in one hand exergy destruction decreases and 
on the other hand the energy requirement of the system is partially or totally met by utilization of the retentate gas.

Based on the exergy evaluation, the best operating conditions are the most intense conditions, i.e. the highest pressure and temperature, and the lowest $\mathrm{S} / \mathrm{C}$ ratio at which carbon deposition is probable. As presented in Fig. 13, lower fuel flow rate is more beneficial. Again it should be mentioned that if higher rate of pure hydrogen is needed (probably by a fuel cell fed online), the higher fuel flow rate is needed. However, it is obvious that the difference between exergy efficiencies at two fuel flow rates at the same pressure, temperature, and S/C ratio, is not negligible.

The exergy efficiency values obtained in this work are comparable to the related ones in the literature. In the work by Hedayati et al. [26], the exergy efficiency of an insulated reactor placed between 30-455 at $923 \mathrm{~K}$. however, they showed that huge amount of exergy is lost by the retentate gas stream due to presence of large amount of unconverted methane. In another modeling works by Khila et al. [19] and Tippawan et al. [24], exergy efficiencies of $72 \%$ and $60 \%$ were reported, respectively, for the ESR process. The heat losses were neglected, and the results obtained were based on process modeling using Aspen Plus. Besides, total hydrogen production was considered for exergy evaluation of the process.

As the field of membrane science and pure hydrogen production in catalytic membrane reactors is growing, exergetic evaluation of the CMR systems -as the first essential step for system analysis via exergonomic optimization- represents a new tool in this science to approach larger scale applications.

\section{Conclusion}

ESR experiments over $\mathrm{Pd}-\mathrm{Rh} / \mathrm{CeO}_{2}$ were performed in a CMR containing $\mathrm{Pd}-\mathrm{Ag}$ separation membranes using ethanol and water mixtures at different $\mathrm{S} / \mathrm{C}$ ratios. Hydrogen yield of 0.55 and hydrogen recovery of $90 \%$ were reached at $923 \mathrm{~K}$ and 12 bar as a result of the special 
configuration of the CMR. More than $0.9 \mathrm{I}_{\mathrm{N}}$ of pure hydrogen permeated per ml ethanol in fuel at 12 bar and $923 \mathrm{~K}$ were obtained. Thanks to the shift effect, methane steam reforming reaction was promoted to a large extent at unfavorable conditions of high pressures. The application of exergy analysis was introduced as a relevant tool to explain the effects of operating conditions and thermodynamic losses on both pure hydrogen production rate and total efficiency of the CMR. Both insulated and non-insulated reforming systems were evaluated in terms of exergy destruction, exergy efficiency, and thermal efficiency. The effects of pressure and temperature were dominant. The exergy efficiency increased with pressure because of the shift effect where more methane was converted at higher pressure. The highest exergy destruction occurred via heat losses and the retentate gas stream. The reforming system reached around $50 \%$ exergy efficiency at $923 \mathrm{~K}$ and 12 bar in the case of an insulated reactor. In the case of recovery of the retentate gas and insulation of the reactor, exergy efficiency placed between $70-90 \%$. It was concluded that operating at the highest pressure, the lowest $\mathrm{S} / \mathrm{C}$ ratio and at $923 \mathrm{~K}$ gives the best exergy efficiency. The consideration of the thermal efficiency revealed that while thermal efficiency offers an ideal performance at high pressure and temperature, exergy efficiency discloses inevitable irreversibilities even when the reactor is insulated.

\section{Acknowledgments}

Funding from MINECO project ENE2012-36368 is acknowledged. Ali Hedayati gratefully acknowledges Erasmus Mundus Joint Doctoral Program SELECT+. Jordi Llorca is Serra Húnter Fellow and is grateful to ICREA Academia program.

\section{References}

[1] A.P. Simpson, A. Lutz, Exergy analysis of hydrogen production via steam methane reforming, International Journal of Hydrogen Energy. 32 (2007) 4811-4820. doi:10.1016/j.ijhydene.2007.08.025.

[2] G.A. Deluga, J.R. Salge, L.D. Schmidt, X.E. Verykios, Renewable hydrogen from ethanol by autothermal reforming., Science (New York, NY). 303 (2004) 993-997. doi:10.1126/science.1093045. 
[3] G. Rabenstein, V. Hacker, Hydrogen for fuel cells from ethanol by steam-reforming, partialoxidation and combined auto-thermal reforming: A thermodynamic analysis, Journal of Power Sources. 185 (2008) 1293-1304. doi:10.1016/j.jpowsour.2008.08.010.

[4] P.D. Vaidya, A.E. Rodrigues, Insight into steam reforming of ethanol to produce hydrogen for fuel cells, Chemical Engineering Journal. 117 (2006) 39-49. doi:10.1016/j.cej.2005.12.008.

[5] A. Haryanto, S. Fernando, N. Murali, S. Adhikari, Current Status of Hydrogen Production Techniques by Steam Reforming of Ethanol : A Review, ENERGY \& FUELS. (2005) 20982106.

[6] M. Ni, D.Y.C. Leung, M.K.H. Leung, A review on reforming bio-ethanol for hydrogen production, International Journal of Hydrogen Energy. 32 (2007) 3238-3247. doi:10.1016/j.ijhydene.2007.04.038.

[7] Llorca J, Cortés Corberán V., Divins J.N., Fraile R.O., Elena Taboada E., Hydrogen from bio-ethanol, in: D. Gandía LM, Arzamendi G, E. PM (Eds.), Renewable Hydrogen Technologies, Elsevier, Amsterdam, 2013. doi:10.1016/B978-0-444-56352-1.00007-6.

[8] J.L. Contreras, J. Salmones, J.A. Colín-Luna, L. Nuño, B. Quintana, I. Córdova, et al., Catalysts for $\mathrm{H} 2$ production using the ethanol steam reforming (a review), International Journal of Hydrogen Energy. 39 (2014) 18835-18853. doi:10.1016/j.ijhydene.2014.08.072.

[9] E. Lopez, V. Gepert, A. Gritsch, U. Nieken, G. Eigenberger, Ethanol Steam Reforming Thermally Coupled with Fuel Combustion in a Parallel Plate Reactor, Industrial \& Engineering Chemistry Research. 51 (2012) 4143-4151. doi:10.1021/ie202364y.

[10] H. Idriss, M. Scott, J. Llorca, S.C. Chan, W. Chiu, P.-Y. Sheng, et al., A phenomenological study of the metal-oxide interface: the role of catalysis in hydrogen production from renewable resources., ChemSusChem. 1 (2008) 905-10. doi:10.1002/cssc.200800196.

[11] M. Domínguez, E. Taboada, E. Molins, J. Llorca, Ethanol steam reforming at very low temperature over cobalt talc in a membrane reactor, Catalysis Today. 193 (2012) 101-106. doi:10.1016/j.cattod.2012.02.004.

[12] M.A. Murmura, M. Patrascu, M.C. Annesini, V. Palma, C. Ruocco, M. Sheintuch, Directing selectivity of ethanol steam reforming in membrane reactors, International Journal of Hydrogen Energy. 40 (2015) 5837-5848. doi:10.1016/j.ijhydene.2015.03.013.

[13] A. Basile, Hydrogen Production Using Pd-based Membrane Reactors for Fuel Cells, Topics in Catalysis. 51 (2008) 107-122. doi:10.1007/s11244-008-9128-6.

[14] D. Mendes, S. Tosti, F. Borgognoni, A. Mendes, L.M. Madeira, Integrated analysis of a membrane-based process for hydrogen production from ethanol steam reforming, Catalysis Today. 156 (2010) 107-117. doi:10.1016/j.cattod.2010.02.029.

[15] S. Tosti, A. Basile, L. Bettinali, F. Borgognoni, F. Gallucci, C. Rizzello, Design and process study of Pd membrane reactors, International Journal of Hydrogen Energy. 33 (2008) 50985105. doi:10.1016/j.ijhydene.2008.05.031.

[16] F. Gallucci, A. Basile, Pd-Ag membrane reactor for steam reforming reactions: A comparison between different fuels, International Journal of Hydrogen Energy. 33 (2008) 1671-1687. doi:10.1016/j.ijhydene.2008.01.010.

[17] M.M. Adrian bejan, George Tsatsarnois, Thermal Design and optimization.pdf, John Wiley, New York, USA, 1996.

[18] N. Sato, Chemical Energy and Exergy, Elsevier Science \& Technology Books, Amsterdam, 2004.

[19] Z. Khila, N. Hajjaji, M.-N. Pons, V. Renaudin, A. Houas, A comparative study on energetic and exergetic assessment of hydrogen production from bioethanol via steam reforming, partial oxidation and auto-thermal reforming processes, Fuel Processing Technology. 112 
(2013) 19-27. doi:10.1016/j.fuproc.2013.02.013.

[20] Y. Casas-Ledón, L.E. Arteaga-Perez, M.C. Morales-Perez, L.M. Peralta-Suárez, Thermodynamic Analysis of the Hydrogen Production from Ethanol: First and Second Laws Approaches, ISRN Thermodynamics. 2012 (2012) 1-8. doi:10.5402/2012/672691.

[21] Y. Kalinci, A. Hepbasli, I. Dincer, Efficiency assessment of an integrated gasifier/boiler system for hydrogen production with different biomass types, International Journal of Hydrogen Energy. 35 (2010) 4991-5000. doi:10.1016/j.jjhydene.2009.08.079.

[22] A. Modarresi, W. Wukovits, A. Friedl, Application of exergy balances for evaluation of process configurations for biological hydrogen production, Applied Thermal Engineering. 30 (2010) 70-76. doi:10.1016/j.applthermaleng.2009.04.027.

[23] Y. Casas-Ledón, L.E. Arteaga-Perez, M.C. Morales-Perez, L.M. Peralta-Suárez, Thermodynamic Analysis of the Hydrogen Production from Ethanol: First and Second Laws Approaches, ISRN Thermodynamics. 2012 (2012). doi:10.5402/2012/672691.

[24] P. Tippawan, A. Arpornwichanop, Energy and exergy analysis of an ethanol reforming process for solid oxide fuel cell applications., Bioresource Technology. 157 (2014) 231-9. doi:10.1016/j.biortech.2014.01.113.

[25] Z. Khila, N. Hajjaji, M.-N. Pons, V. Renaudin, A. Houas, A comparative study on energetic and exergetic assessment of hydrogen production from bioethanol via steam reforming, partial oxidation and auto-thermal reforming processes, Fuel Processing Technology. 112 (2013) 19-27. doi:10.1016/j.fuproc.2013.02.013.

[26] A. Hedayati, O. Le Corre, B. Lacarrière, J. Llorca, Exergetic study of catalytic steam reforming of bio-ethanol over $\mathrm{Pd}-\mathrm{Rh} / \mathrm{CeO} 2$ with hydrogen purification in a membrane reactor, International Journal of Hydrogen Energy. 40 (2015) 3574-3581. doi:10.1016/j.ijhydene.2014.09.016.

[27] E. López, N.J. Divins, J. Llorca, Hydrogen production from ethanol over Pd-Rh/CeO2 with a metallic membrane reactor, Catalysis Today. 193 (2012) 145-150. doi:10.1016/j.cattod.2012.06.030.

[28] Reb Research \& Consulting, accessed on 2015-09-23, http://www.rebresearch.com/, (2015). http://www.rebresearch.com/ (accessed September 23, 2015).

[29] M.K. Cohce, I. Dincer, M. a Rosen, Energy and exergy analyses of a biomass-based hydrogen production system., Bioresource Technology. 102 (2011) 8466-74. doi:10.1016/j.biortech.2011.06.020.

[30] NASA polynomials, University of California, Berkeley. (n.d.). http://www.me.berkeley.edu/grimech/data/nasa_plnm.html.

[31] G.D. R. J. Kee, F. M. Rupley, J. A. Miller, M. E. Coltrin, J. F. Grcar, E. Meeks, H. K. Moffat, A. E. Lutz, W.C.R. M. D. Smooke, J. Warnatz, G. H. Evans, R. S. Larson, R. E. Mitchell, L. R. Petzold, and O.A. M. Caracotsios, W. E. Stewart, P. Glarborg, C. Wang, Chemkin Thermodynamic Database, Reaction Design, San Diegp, CA, 2000.

file://C:/Users/Ali/Desktop/chemkin polynomial coefficient.pdf.

[32] A.P. Hinderink, F.P.J.M. Kerkhof, A.B.K. Lie, J. De Swaan Arons, H.J. Van Der Kooi, Exergy analysis with a flowsheeting simulator-I. Theory; calculating exergies of material streams, Chemical Engineering Science. 51 (1996) 4693-4700. doi:10.1016/00092509(96)00220-5.

[33] S. Tosti, A. Basile, F. Borgognoni, V. Capaldo, S. Cordiner, S. Di Cave, et al., Low temperature ethanol steam reforming in a Pd-Ag membrane reactorPart 1: Ru-based catalyst, Journal of Membrane Science. 308 (2008) 250-257. doi:10.1016/j.memsci.2007.10.001.

[34] A. Basile, F. Gallucci, A. Iulianelli, S. Tosti, CO-Free Hydrogen Production by Ethanol 
Steam Reforming in a Pd-Ag Membrane Reactor, Fuel Cells. 8 (2008) 62-68. doi:10.1002/fuce.200700018.

[35] A.M. da Silva, L. V. Mattos, J. Múnera, E. Lombardo, F.B. Noronha, L. Cornaglia, Study of the performance of $\mathrm{Rh} / \mathrm{La2O} 3-\mathrm{SiO} 2$ and $\mathrm{Rh} / \mathrm{CeO} 2$ catalysts for SR of ethanol in a conventional fixed-bed reactor and a membrane reactor, International Journal of Hydrogen Energy. 40 (2015) 4154-4166. doi:10.1016/j.ijhydene.2015.01.106.

[36] A. Basile, F. Gallucci, A. Iulianelli, M. De Falco, S. Liguori, Hydrogen Production by Ethanol Steam Reforming: Experimental Study of a Pd-Ag Membrane Reactor and Traditional Reactor Behaviour, International Journal of Chemical Reactor Engineering. 6 (2008). doi:10.2202/1542-6580.1591.

[37] D. Sundararajan, A.-M. Azad, Cooperative Synergy in Nanoscale Ceria-Based Systems, Science of Advanced Materials. 3 (2011) 739-762. doi:10.1166/sam.2011.1202. 